\title{
Pengaruh Pemberian Level Protein Berbeda terhadap Performans Produksi Itik Umur 2-10 Minggu di Sumba Timur
}

\author{
Effect of Different Protein Level on Performans Production of Ducks Aged 2-8 weeks \\ in Sumba Timur
}

\author{
R. R. Dapawole ${ }^{1}$ dan I. M. A. Sudarma ${ }^{1,2}$ \\ ${ }^{1}$ Program Studi Peternakan Universitas Kristen Wira Wacana Sumba \\ Jl. R. Soeprapto No. 35, Waingapu 87113 \\ ${ }^{2}$ Corresponding email : adi_dharma17@yahoo.com
}

\begin{abstract}
Ducks always raised as dual purpose by local farmers and it is focus to produce eggs than meat. Therefore, the meat is solid due to the age of ducks. The study aimed to test protein level on ducks feed and to know the ducks performance on production at aged 2-10 weeks. This study used complete random design $4 \times 3$ with 4 treatment of protein levels. Those were $\mathrm{R}_{1}(\mathrm{CP} 9 \%), \mathrm{R}_{2}$ (CP 12\%), $\mathrm{R}_{3}$ (CP 15\%) and $\mathrm{R}_{4}(\mathrm{CP} 18 \%)$ which had been presented to 36 ducks aged 2 weeks during 8 weeks in Sumba Timur region. The result showed the $R_{1}$ had poor performance on production and significant different on $R_{2}, R_{3}$ and $R_{4}$. The treatments of $R_{2}, R_{3}$ and $R_{4}$ had no different significance in performance production of body weight cumulative $(1.382,50-1.583,61 \mathrm{~g} / \mathrm{e} / 8$ week), feed consumption (805.33-822.88 g/e/d), average daily gain (142.24-170.49 g/e/d), cumulative gain $(1,137.92$ $1,363.89 \mathrm{~g} / \mathrm{e} / 8$ week) and mortality rate $(0 \%)$. The feed convertion rate of $\mathrm{R}_{2}(5.70)$ had significant different on $\mathrm{R}_{3}$ and $\mathrm{R}_{4}$ (4.86 and 4.90 respectively). It concluded that $\mathrm{R}_{3}$ can be used as complete feed to fatten ducks aged 210 weeks which had good performance of production with lowest feed convertion rate and competitive price.
\end{abstract}

Key word : local ducks, protein level, fattening, complete feed, performance production

\begin{abstract}
ABSTRAK
Itik selalu dipelihara oleh petani lokal sebagai ternak dwi fungsi yang mana lebih diprioritaskan untuk menghasilkan telur dari pada daging sehingga itik dipotong pada saat umur tua yang menyebabkan kerasnya daging itik tersebut. Penelitian ini bertujuan untuk menguji level protein dalam ransum itik untuk mengetahui performans produksi itik umur 2-10 minggu. Penelitian ini menggunakan RAL $4 \times 3$ dengan 4 level protein $R_{1}$ (PK 9\%), $\mathrm{R}_{2}$ (PK 12\%), $\mathrm{R}_{3}$ (PK 15\%) dan $\mathrm{R}_{4}$ (PK 18\%) pada 36 ekor itik umur 2 minggu selama 8 minggu masa pemeliharaan di Kabupaten Sumba Timur. Hasil penelitian menunjukkan bawah perlakuan $R_{1}$ memiliki performans produksi terrendah dan berbeda nyata dibanding perlakuan $R_{2}, R_{3}$ dan $R_{4}$. Perlakuan $R_{2}, R_{3}$ dan $R_{4}$ tidak berbeda nyata pada variabel bobot badan kumulatif (1.382,50-1.583,61 g/e/8 minggu), konsumsi ransum (805,33-822,88 g/e/h), PBB harian (142,24-170,49 g/e/h), PBB kumulatif (1.137,92-1.363,89 g/e/8 minggu) dan tingkat kematian ternak $(0 \%)$. Rata-rata konversi ransum $\mathrm{R}_{2}(5,70)$ berbeda nyata dibandingkan $\mathrm{R}_{3}$ dan $\mathrm{R}_{4}$ (berturut-turut 4,86 dan 4,90). Disimpulkan bahwa ransum perlakuan $\mathrm{R}_{3}$ dapat digunakan sebagai pakan komplit untuk penggemukan ternak itik umur 2-10 minggu yang mana menunjukkan performans produksi yang baik dengan konversi ransum terendah dan harga ransum yang kompetitif.
\end{abstract}

Kata kunci : Itik lokal, level protein, penggemukan, ransum komplit, performans produksi

\section{PENDAHULUAN}

Itik di Indonesia umumnya diusahakan sebagai unggas penghasil telur dengan sistem pemeliharaan semi intensif dimana dibiarkan mencari makan di perairan seperti sawah pada siang hari dan dikandangkan dan diberi pakan pada malam maupun pagi hari. Itik sebagai penghasil daging belum begitu banyak dikembangkan atau diusahakan karena tertutupi oleh dwi fungsi itik yang sebagai penghasil telur sehingga umumnya itik betina dan jantan afkir yang dijadikan sebagai produksi daging. Hal ini tentunya akan menurunkan nilai jual ternak itik dikalangan masyarakat karena kualitas daging itik afkir tentu lebih rendah dibandingkan itik muda sehingga ketersediaanya relatif masih rendah.

Dari segi kandungan gizi, daging itik tidak kalah bersaing dengan kandungan gizi daging ayam dimana kandungan protein daging itik cukup tinggi sekitar 18,6-20,8\% sementara daging ayam $21,4-22,6 \%$, demikian juga kandungan lemaknya $2,7-8,2 \%$ sementara 
daging ayam 4,8\% (Jun et al., 1996; Srigandono 1997; Kim et al. 2006 dalam Matitaputty dan Bansi, 2016). Kelebihan ternak itik lokal dibanding ayam kampung di tingkat petani pedesaan adalah rendahnya laporan kematian itik karena penyakit, dimana umumnya ternak itik dan itik manila lebih tahan terhadap penyakit dibandingkan ayam kampung.

Adapun Populasi ternak itik di Indonesia tahun 2017 sebanyak 49.709.403 ekor, mengalami pertumbuhan $4,82 \%$ dari tahun sebelumnya, sementara untuk produksi daging sebesar 43,15 ton (Statistik Pertanian, 2017). Pada tahun 2016 Provinsi Nusa Tenggara Timur (NTT) menyumbang populasi ternak itik sebesar 344.942 ekor sedangkan Kabupaten Sumba Timur sebesar 2.873 ekor atau $0,83 \%$ dari total populasi ternak itik di NTT (Dinas Peternakan NTT, 2016). Hal ini mengindikasikan ternak itik belum banyak diternakkan di daerah Sumba Timur sehingga perlu dikembangkan sebagai usaha potensial baik dari sistem pemeliharaan, jenis pakan, jumlah pakan, maupun lama pemeliharaannya di tingkat penelitian yang bisa dijadikan rekomendasi untuk petani peternak di Sumba Timur.

Hasil penelitian pakan ternak itik dengan menggunakan tingkatan pakan polar hingga 50\% dalam ransum memperlihatkan tingkat konsumsi sebesar 6.111 gram/ekor dengan rataan konversi pakan sebesar 3,47 dan PBB 1.759 gram/ekor pada ternak itik Serati selama 8 minggu (Ketaren, $\left.2006^{\mathrm{a}}\right)$. Ketaren $\left(2006^{\mathrm{b}}\right)$ juga memperlihatkan hasil penelitian pada ternak itik Serati yang mengkonsumsi pakan dengan kandungan dedak padi tinggi $(72,5 \%)$ memililki nilai konversi pakan yang cukup baik yakni sebesar 4,17-5,58 dengan PBB sebesar 1.265-1.409 gram/ekor selama 8 minggu pemeliharaan. Namun, sistem pemeliharaan ternak itik lokal oleh petani peternak di Indonesia umumnya dan di Kabupaten Sumba Timur khususnya masih bersifat semi intensif dengan pakan utama berupa jagung dan polar perlu dikembangkan dan diteliti sehingga diketahui potensi konsumsi pakan, nilai konversi pakan, maupun pertambahan bobot badan yang dihasilkan.

\section{MATERI DAN METODE}

\section{Ternak dan Ransum Percobaan}

Penelitian ini menggunakan itik lokal sebanyak 36 ekor, dengan rata-rata umur 2 minggu. Ransum yang diberikan berupa pakan yang terdiri dari jagung, polar, brem, tepung ikan dan mineral mix dengan kandungan nutrisi diformulasikan dengan level protein yang berbeda. Ransum diberikan dalam bentuk mash secara adlibitum dan dihitung sisa pakan setiap minggunya. Air diberikan secara adlibitum dan diganti setiap harinya.

\section{Perlakuan, Rancangan Percobaan dan Analisis data}

Dalam penyusunan ransum penelitian ini tidak menggunakan bahan pakan dedak halus karena berdasarkan hasil analisis proksimat (Tabel 1) menunjukkan adanya komposisi nutrisi dedak halus yang kurang bagus karena kandungan serat kasar yang sangat tinggi dengan kandungan protein yang rendah sehingga komposisinya diganti dengan bahan pakan Brem. Berdasarkan komposisi ransum yang dibuat, harga ransum $\mathrm{R}_{1}, \mathrm{R}_{2}, \mathrm{R}_{3}, \mathrm{R}_{4}$ berturut-turut adalah Rp 5.630, Rp 5.810, Rp 5.990 dan Rp 6.170.

Penelitian ini menggunakan Rancangan Acak Lengkap (RAL) dengan 4 perlakuan dan 3 ulangan dimana masing-masing ulangan terdapat 3 ekor itik. Adapun perlakuan level protein yang diujicobakan sebagai berikut : $\mathrm{R}_{1}=$ Ransum dengan level protein 9\%; $\mathrm{R}_{2}=$ Ransum dengan level protein $12 \% ; \mathrm{R}_{3}=$ Ransum dengan level protein 15\%; dan $\mathrm{R}_{4}=$ Ransum dengan level protein 18\%. Data yang diperoleh dianalisis dengan menggunakan analisis sidik ragam ANOVA, dimana perbedaan antara perlakuan dinyatakan berbeda nyata pada taraf $\mathrm{P}<0,05$. Data dianalisis menggunakan software SPSS 18,0 for windows.

Tabel 1. Kandungan nutrisi bahan pakan

\begin{tabular}{llllll}
\hline Kode sampel & BK $(\%)$ & BO $(\% \mathrm{BK})$ & PK $(\% \mathrm{BK})$ & LK $(\% \mathrm{BK})$ & SK $(\% \mathrm{BK})$ \\
\hline Tepung ikan & 82,219 & 71,174 & 56,074 & 5,685 & 3,753 \\
Polar & 87,554 & 82,625 & 18,459 & 5,029 & 9,116 \\
Brem & 88,679 & 83,279 & 11,128 & 2,974 & 10,582 \\
Dedak & 88,928 & 74,095 & 5,386 & 2,797 & 26,431 \\
Jagung & 87,427 & 85,146 & 7,327 & 3,445 & 2,870 \\
\hline
\end{tabular}

Sumber : Hasil analisis kandungan nutrisi bahan pakan di Laboratorium Kimia Pakan Undana Kupang 
Tabel 2. Komposisi dan kandungan protein ransum perlakuan

\begin{tabular}{lcccccccc}
\hline Bahan & \multicolumn{2}{c}{ Perlakuan $\mathrm{R}_{1}$} & \multicolumn{2}{c}{ Perlakuan $\mathrm{R}_{2}$} & \multicolumn{2}{c}{ Perlakuan $\mathrm{R}_{3}$} & \multicolumn{2}{c}{ Perlakuan $\mathrm{R}_{4}$} \\
\cline { 2 - 8 } Pakan & Komposisi & PK & Komposisi & PK & Komposisi & PK & Komposisi & PK \\
\hline Jagung & $70 \%$ & $5,13 \%$ & $60 \%$ & $4,40 \%$ & $50 \%$ & $3,66 \%$ & $40 \%$ & $2,93 \%$ \\
Polar & $15 \%$ & $2,77 \%$ & $20 \%$ & $3,69 \%$ & $25 \%$ & $4,61 \%$ & $30 \%$ & $5,54 \%$ \\
T.Ikan & $0 \%$ & $0,00 \%$ & $5 \%$ & $2,80 \%$ & $10 \%$ & $5,61 \%$ & $15 \%$ & $8,41 \%$ \\
Brem & $10 \%$ & $1,11 \%$ & $10 \%$ & $1,11 \%$ & $10 \%$ & $1,11 \%$ & $10 \%$ & $1,11 \%$ \\
Mineral & $5 \%$ & $0,00 \%$ & $5 \%$ & $0,00 \%$ & $5 \%$ & $0,00 \%$ & $5 \%$ & $0,00 \%$ \\
Total & $100 \%$ & $9,01 \%$ & $100 \%$ & $12,00 \%$ & $100 \%$ & $15,00 \%$ & $100 \%$ & $17,99 \%$ \\
\hline
\end{tabular}

\section{HASIL DAN PEMBAHASAN}

\section{Bobot Hidup Ternak Itik}

Bobot hidup ternak itik umur 2 minggu yang digunakan dalam penelitian ini adalah $239,55 \pm 15,57$ gram. Selama 8 minggu masa pemeliharaan bobot badan itik tertinggi mencapai bobot 2.205 gram. Hasil penelitian menunjukkan bahwa itik yang mendapat perlakuan pakan $\mathrm{R}_{1}$ (PK 9\%) memiliki bobot badan pada minggu ke8 yang sangat rendah yaitu 490,00 $\pm 42,72$ gram/ekor. Performans bobot badan itik yang mendapat ransum perlakuan $\mathrm{R}_{2}, \mathrm{R}_{3}$ dan $\mathrm{R}_{4}$ selama 8 minggu tidak jauh berbeda berturut-turut $1.382,50 \pm 91,31$ gram/ekor; $1.583,61 \pm 200,98$ gram/ekor; dan 1.554,03 $\pm 199,97$ gram/ekor. Penggunaan ransum dengan level protein $12-18 \%$ ini tidak jauh berbeda dengan hasil penelitian Purba dan Ketaren (2011) dimana rataan bobot hidup itik pada umur 8 minggu berkisar antara $1.425,72$ hingga $1.500,72$ gram/ekor.

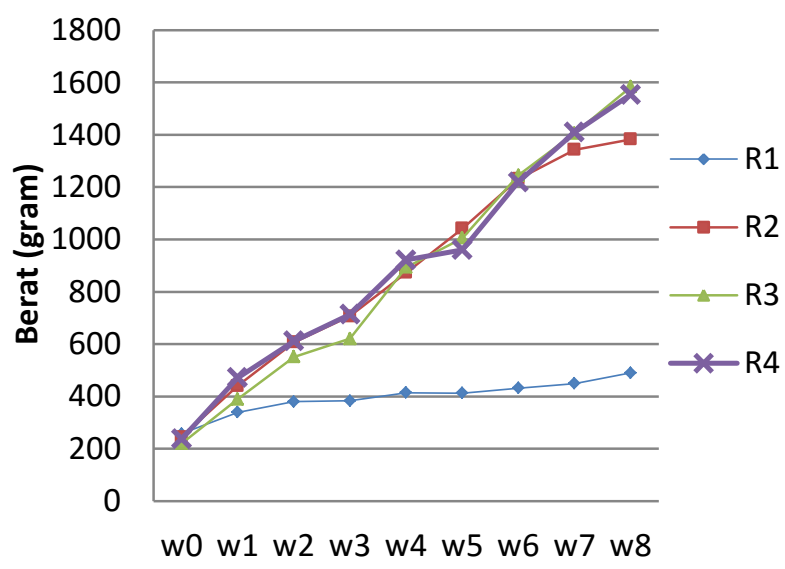

Gambar 1. Grafik tren bobot badan kumulatif itik hingga minggu ke-8

\section{Konsumsi Ransum}

Ransum merupakan sejumlah pakan yang diberikan pada ternak untuk memenuhi kebutuhan hidup ternak tersebut selama 24 jam. Berdasarkan gambar 2 dibawah menunjukkan bahwa pada awal masa pemeliharaan, itik mengkonsumsi ransum ratarata sebanyak $611,77 \pm 73,8$ gram/minggu/ekor. Untuk perlakuan $R_{2}, R_{3}$ dan $R_{4}$ terlihat bahwa adanya tren peningkatan konsumsi ransum hingga $910,00 \pm 70,55$ gram $/$ minggu/ekor pada minggu ke-8. Namun, hal ini berbeda dengan perlakuan $R_{1}$ dimana terlihat adanya tren penurunan konsumsi ternak hingga $366,67 \pm 55,08$ gram/minggu/ekor. Hal ini kemungkinan disebabkan karena rendahnya nutrisi protein yang ada dalam ransum yakni hanya 9\%. Menurut NRC (1994) kebutuhan gizi itik pedaging umur 2 minggu hingga 7 minggu disarankan mengandung protein kasar sebanyak $16 \%$ dan energi metabolis $3.000 \mathrm{kkal} / \mathrm{kg}$ dalam ransum. Hasil penelitian konsumsi ransum ini lebih rendah dibanding hasil penelitian Suprayogi et al. (2017) yang memperlihatkan konsumsi rata-rata itik lokal jantan umur 2-4 minggu adalah sebesar 139,31-143,54 gram/ekor/gari atau setara dengan 975,17-1.004,78 gram/minggu/ekor.

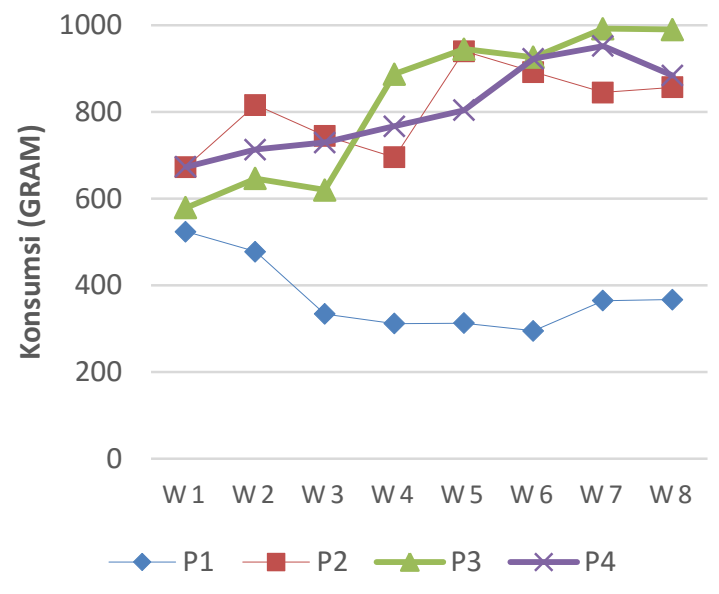

Gambar 2. Grafik rataan konsumsi itik setiap minggu 
Pada Tabel 3 diperlihatkan bahwa ratarata konsumsi ransum perlakuan $R_{1}$ berbeda nyata dengan perlakuan lainnya. Perlakuan $R_{2}, R_{3}$ dan $R_{4}$ tidak memiliki perbedaan yang signifikan dalam mengkonsumsi ransum setiap minggunya. Adapun rata-rata konsumsi kumulatif ternak itik selama 8 minggu (umur 2-10 minggu) dalam penelitian ini adalah $5.618 \pm 1.757$ gram/ekor. Perlakuan $R_{1}$ memiliki jumlah konsumsi kumulatif selama 8 minggu yang paling rendah yakni hanya 2.983 gram/ekor. Perlakuian $R_{2}, R_{3}$ dan $R_{4}$ memiliki jumlah konsumsi ransum kumulatif selama 8 minggu yang hampir sama yaitu berturut-turut 6.461 gram/ekor; 6.583 gram/ekor; dan 6.443 gram/ekor. Hasil penelitian konsumsi ransum kumulatif ini jauh dibawah hasil penelitian Purba dan Ketaren (2011); Randa (2007); maupun Iskandar et al. (2001) yang memperlihatkan bahwa jumlah konsumsi ransum kumulatif ternak itik umur 2-10 minggu (8 minggu masa pemeliharaan) berkisar antara 7.200-7.900 gram/ekor. Namun hasil penelitian ini masih lebih tinggi dari hasil penelitian Ketaren dan Prasetyo (2001) yang memperlihatkan rataan jumlah konsumsi itik MA selama 8 minggu adalah sebanyak 4.324 gram/ekor. Hal ini kemungkinan besar dipengaruhi oleh jenis itik dan jenis bahan pakan dalam ransum yang digunakan termasuk kandungan nutrisi ransum.

Adanya perbedaan konsumsi pakan yang sangat signifikan antara perlakuan $R_{1}$ dengan perlakuan $R_{2}, \quad R_{3}$ maupun $R_{4}$ kemungkinan disebabkan karena rendahnya nilai nutrisi protein dalam ransum. Selain itu, pada perlakuan ransum $\mathrm{R}_{1}$ tidak mengandung bahan pakan tepung ikan sedangkan perlakuan lainnya baik $R_{2}, R_{3}$ dan $R_{4}$ mengandung bahan pakan tepung ikan berturutturut 5\%; 10\%; dan $15 \%$. Adanya penggunaan tepung ikan ini juga kemungkinan ikut mempengaruhi palatabilitas ransum oleh ternak itik untuk mengkonsumsi ransum yang diberikan. Menurut Purba dan Ketaren (2011) selama fase pertumbuhan, itik umumnya membutuhkan pakan yang relatif banyak dan berkualitas agar dapat tumbuh dan berkembang dengan sempurna dan penggunaan tepung ikan dengan level cukup tinggi (hingga 23\% dalam ransum) mampu memicu itik untuk mengkonsumsi pakan dalam jumlah banyak. Fan et al. (2008) juga menyatakan bahwa pemberian pakan yang mengandung energi tinggi dapat meningkatkan konsumsi pakan yang erat dengan pertumbuhan ternak unggas. Tepung ikan selain memiliki kandungan protein yang tinggi $(56,07 \%)$ juga memiliki kandungan lemak yang cukup tinggi $(5,68 \%)$.

\section{Pertambahan Bobot Badan}

Hasil penelitian menunjukkan bahwa pertambahan bobot badan rata-rata mingguan ternak itik umur 2-10 minggu adalah $124,71 \pm 69,88$ gram/minggu/ekor. Rataan pertambahan bobot badan terendah diamati pada perlakuan $R_{1}$ yaitu 21,49 gram/minggu/ekor. Perlakuan $R_{2}, \quad R_{3}$ dan $R_{4}$ memiliki rataan pertambahan bobot badan rata-rata mingguan yang tidak berbeda nyata yaitu berturut-turut 142,24 gram/minggu/ekor; $\quad 170,49$ gram/minggu/ekor; dan 164,64 gram/minggu/ekor. Hasil penelitian ini menunjukkan bahwa ransum ternak itik penggemukan tidak harus mengandung protein yang sangat tinggi hingga 18\% dimana ransum dengan kandungan nutrisi $12 \%$ sudah mampu memberikan tambahan bobot badan rata-rata mingguan yang cukup baik. Namun perlu dikaji lebih lanjut terkait komposisi bahan pakan yang digunakan karena ransum dengan kandungan protein $12 \%$ namun dengan komposisi bahan pakan yang berbeda kemungkinan bisa memberikan hasil yang berbeda.

Tabel 3 Rata-rata konsumsi ransum ternak itik lokal selama 8 minggu (umur 2-10 minggu)

\begin{tabular}{ccc}
\hline \multirow{2}{*}{ Perlakuan } & Konsumsi Ransum Rataan & Konsumsi Ransum Kumulatif \\
\cline { 2 - 3 } & gram/ekor & gram/ekor \\
\hline $\mathrm{R}_{1}$ (PK 9\%) & $372,90^{\mathrm{a}}$ & $2.983,2^{\mathrm{a}}$ \\
$\mathrm{R}_{2}$ (PK 12\%) & $807,64^{\mathrm{b}}$ & $6.461,1^{\mathrm{b}}$ \\
$\mathrm{R}_{3}$ (PK 15\%) & $822,88^{\mathrm{b}}$ & $6.583,1^{\mathrm{b}}$ \\
$\mathrm{R}_{4}$ (PK 18) & $805,33^{\mathrm{b}}$ & $6.442,6^{\mathrm{b}}$ \\
\hline
\end{tabular}

Keterangan : superskrip dengan huruf yang berbeda pada kolom yang sama menunjukkan perbedaan nyata $(\mathrm{P}<0,05)$ 
Tabel 4. Rata-rata pertambahan bobot badan ternak itik selama 8 minggu (umur 2-10 minggu)

\begin{tabular}{lcc}
\hline \multirow{2}{*}{ Perlakuan } & PBB rata-rata mingguan & PBB kumulatif \\
\cline { 2 - 3 } & gram/ekor $^{\mathrm{gram} / \mathrm{ekor}^{\mathrm{a}}}$ \\
\hline R1 (PK 9\%) & $21,49^{\mathrm{a}}$ & $233,06^{\mathrm{a}}$ \\
R2 (PK 12\%) & $142,24^{\mathrm{b}}$ & $1.137,92^{\mathrm{b}}$ \\
R3 (PK 15\%) & $170,49^{\mathrm{b}}$ & $1.363,89^{\mathrm{b}}$ \\
R4 (PK 18) & $164,64^{\mathrm{b}}$ & $1.317,08^{\mathrm{b}}$ \\
\hline
\end{tabular}

Keterangan : superskrip dengan huruf yang berbeda pada kolom yang sama menunjukkan perbedaan nyata $(\mathrm{P}<0,05)$

Berdasarkan Tabel 4. diatas, menunjukkan bahwa pertambahan bobot badan kumulatif ternak itik terendah pada perlakuan $\mathrm{R}_{1}$ (PK 9\%) dan tertinggi pada perlakuan $\mathrm{R}_{3}(\mathrm{PK}$ $16 \%$ ). Adapun pertambahan bobot badan kumulatif selama 8 minggu untuk perlakuan $\mathrm{R}_{1}$ berbeda nyata dengan perlakuan $R_{2}, R_{3}$ dan $R_{4}$. Rata-rata konsumsi pada perlakuan $R_{2}, R_{3}$ dan $R_{4}$ tidak ada perbedaan yang signifikan. Hasil penelitian rata-rata konsumsi pada $R_{2}, R_{3}$ dan $R_{4}$ ini tidak jauh berbeda dari hasil penelitian lainnya dimana pertambahan bobot badan kumulatif selama 8 minggu pada ternak itik umur 2-10 minggu berkisar antara 1.260 gram/ekor (Ketaren dan Prasetyo, 2001); dan 1.391,121.466,32 gram/ekor (Purba dan Ketaren, 2011). Namun hasil penelitian ini sedikit lebih tinggi dibanding hasil penelitian Iskandar et al. (2001) yang hanya menghasilkan besaran PBB kumulatif ternak itik jantan lokal sebesar 1.138 gram/ekor; demikian juga dengan hasil penelitian Randa (2007) yang memperlihatkan rataan PBB itik Citaheup jantan umur 10 minggu sebesar 1.154,69 gram/ekor. Hasil penelitian Dewanti et al. (2009) juga menunjukkan tidak adanya perbedaan PBB yang signifikan pada ternak itik Turi yang diberikan level protein yang berbeda (17\%, 18\% dan 19\%).

Hasil penelitian lain yang cukup menarik ditunjukkan oleh Suryana et al. (2014) yang memperlihatkan adanya perbedaan bobot badan dari ternak itik pedaging umur 10 minggu yang berbeda nyata pada masing-masing perlakuan pakan dengan level protein berbeda yakni 915,79 gram/ekor (pakan pola petani); 1.145,65 gram/ekor (PK 14\%); 1.247,82 gram/ekor (PK $16 \%$ ) dan 1.545,74 gram/ekor (PK 18\%). Dari hasil penelitian ini diketahui bahwa pakan pola petani hanya menghasilkan bobot badan sebanyak 915 gram selama 8 minggu. Rendahnya pertambahan bobot badan ini memberikan peluang besar bagi petani untuk memanfaatkan ransum yang dikomposisikan dengan baik. Hasil penelitian dengan nutrisi ransum cukup $12 \%$ PK sudah mampu menghasilkan pertambahan bobot badan hingga 1.137,9 $\pm 83,06$ gram/ekor.

\section{Konversi Pakan}

Konversi ransum merupakan salah satu indikator penting untuk mengukur keberhasilan suatu ransum dalam menghasilkan daging (Tabel 5). Rata-rata konversi ransum ternak itik selama 8 minggu dalam penelitian ini menunjukkan bahwa konversi ransum perlakuan $R_{1}$ berbeda nyata dengan perlakuan ransum $R_{2}, R_{3}$ dan $R_{4}$, sedangkan perlakuan $R_{3}$ dan $R_{4}$ tidak menunjukkan adanya perbedaan konversi ransum yang nyata.

Tabel 5. Rata-rata konversi ransum ternak itik lokal selama 8 minggu (umur 2-10 minggu)

\begin{tabular}{lc}
\hline \multicolumn{1}{c}{ Perlakuan } & Konversi Ransum \\
\hline R1 (PK 9\%) & $13,21^{\mathrm{a}}$ \\
R2 (PK 12\%) & $5,70^{\mathrm{b}}$ \\
R3 (PK 15\%) & $4,86^{\mathrm{c}}$ \\
R4 (PK 18) & $4,90^{\mathrm{c}}$ \\
\hline
\end{tabular}

Keterangan : superskrip dengan huruf yang berbeda pada kolom yang sama menunjukkan perbedaan nyata $(\mathrm{P}<0,05)$

Konversi ransum paling tinggi berada pada perlakuan $R_{1}(13,21)$ yang menujukkan bahwa ransum $\mathrm{R}_{1}$ sama sekali tidak dianjurkan untuk digunakan sebagai ransum ternak itik. Konversi ransum paling rendah berada pada perlakuan $R_{3}$ dan $R_{4}$ yakni 4,8-4,9. Hasil penelitian konversi ransum ini masih lebih tinggi dibanding hasil penelitian pada itik serati dan itik MA dengan FCR selama 8 minggu pemeliharaan berada pada kisaran 3,39-3,47 (Ketaren, 2006 ; Ketaren dan Prasetyo, 2001). Namun hasil penelitian konversi ransum ini masih jauh lebih baik dibanding hasil penelitian Purba dan Ketaren (2011) yang memperlihatkan konversi ransum sebesar 5,03 $\pm 0,06$ hingga 5,35 $\pm 0,25$. Iskandar et al. (2001) juga memperlihatkan adanya rataan konversi ransum yang tinggi pada 
itik mojosari yakni sebesar 6,59 yang diberikan ransum 20\% ikan rucah dan 80\% dedak. Konversi ransum yang berbeda ini mengindikasikan adanya perbedaan yang cukup tinggi jika ransum dibuat dari bahan pakan yang berbeda. Ransum $\mathrm{R}_{3}$ dapat dijadikan ransum komplit ternak itik penggemukan yang menawarkan nilai konversi ransum yang rendah dengan harga ransum yang lebih kompetitif yakni $\mathrm{Rp} 5.990 / \mathrm{kg}$ dibanding ransum $\mathrm{R}_{4}(\mathrm{Rp} 6.170 / \mathrm{kg})$.

\section{Mortalitas}

Pada masa pemeliharaan ternak itik umur 2-10 minggu menunjukkan adanya kematian ternak sebanyak 2 ekor pada perlakuan $\mathrm{R}_{1}$ (Tabel 6). Hal ini memperlihatkan bahwa perlakuan ransum $\mathrm{R}_{1}$ sangat tidak direkomendasikan sebagai ransum ternak itik umur 2-10 hari karena rendahnya produksi yang diberikan, angka konversi ransum yang tinggi hingga dapat menyebabkan kematian pada ternak.

Tabel 6 Rata-rata angka mortalitas ternak itik lokal selama 8 minggu (umur 2-10 minggu)

\begin{tabular}{lc}
\hline Perlakuan & Mortalitas (ekor) \\
\hline R1 (PK 9\%) & 2 \\
R2 (PK 12\%) & 0 \\
R3 (PK 15\%) & 0 \\
R4 (PK 18) & 0 \\
\hline
\end{tabular}

Hasil penelitian Purba dan Ketaren (2011) maupun Matitaputty dan Bansi (2016) menunjukkan bahwa pemeliharaan ternak itik hingga umur 8 minggu maupun selama 12 minggu tidak menunjukkan adanya kematian ternak karena menggunakan ransum yang sudah memenuhi kebutuhan nutrisi minimal ternak untuk bertahan hidup dan berproduksi.

\section{KESIMPULAN}

Berdasarkan hasil pembahasan disimpulkan bahwa ransum dengan tingkat level protein minimal $12 \%$ cukup mampu memberikan performans produksi pada ternak itik yang baik selama masa pemeliharaan 8 minggu. Ransum $\mathrm{R}_{3}$ dengan level protein $15 \%$ disarankan sebagai ransum utama penggemukan ternak itik karena mampu memberikan performans produksi terbaik dengan konversi pakan paling rendah $(4,86)$ dan harga ransum yang kompetitif ( $\mathrm{Rp} 5.990 / \mathrm{kg}$ ). Perlu dilakukan penelitian lanjutan terhadap performans ternak itik yang mengkonsumsi ransum dengan level energi yang berbeda sehingga bisa disusun ransum komplit untuk ternak itik penggemukan umur 2-10 minggu.

\section{UCAPAN TERIMA KASIH}

Kami mengucapkan terima kasih kepada DRPM - Kemenristekdikti yang telah mendanai seluruh pembiayaan kegitan penelitian ini dan LPPM - Unkriswina Sumba yang memfasilitasi peneliti sehingga bisa mendapatkan dana penelitian skema Penelitian Dosen Pemula.

\section{DAFTAR PUSTAKA}

Dewanti, R., J. H. P. Sidadolog, dan Zuprizal. 2009. Pengaruh Pejantan dan Pakan terhadap Pertumbuhan Itik Turi sampai Umur Delapan Minggu. Buletin Peternakan 33 (2): 88-95.

Dinas Peternakan NTT. 2016. Statistik Pertanian Provinsi Nusa Tenggara Timur. Badan Pusat Statistik NTT.

Fan, H. P., M. Xie, W.W. Wang, S. S. Hou and W. Huang. 2008. Effect of Dietary Energy on Growth Performance and Carcass Quality of White Growing Pekin Ducks from Two to Six Weeks Of Age. Poult. Sci. 87: 1162-1164.

Iskandar, S., Vanvan S. Nugroho, D. M. Suci and A. R. Setioko. 2001. Adaptasi Biologis Itik Jantan Muda Lokal terhadap Ransum Berkadar Dedak Padi Tinggi. Pros. Lokakarya Unggas Air. Pengembangan Agribisnis Unggas Air sebagai Peluang Usaha Baru. Ciawi, 5-6 Agustus 2001. Fakultas Peternakan IPB Bogor-Balai Penelitian Ternak. Bogor. hlm. 118-127.

Ketaren, P. P dan L. H. Prasetyo. 2001. Pengaruh Pemberian Pakan Terbatas Terhadap Penampilan Itik Silang Mojosari x Alabio (MA) Umur 8 Minggu. Pros. Lokakarya Unggas Air. Pengembangan Agribisnis Unggas Air Sebagai Peluang Usaha Baru. Ciawi, 5-6 Agustus 2001. Fakultas Peternakan IPB Bogor-Balai Penelitian Ternak, Bogor. Hlm. 105-110.

Ketaren, P. P. 2006 ${ }^{\mathrm{a}}$. Optimalisasi Pemanfaatan Wheat Bran Untuk Produksi Daging 
Unggas Melalui Suplementasi Enzim Xilanase dan $\beta$-Glukanase: Itik pedaging. Pros. Seminar Nasional Bioteknologi. Cibinong, 15 - 16 Nopember 2006. Puslit Bioteknologi, LIPI, Cibinong. hlm. $325-331$.

Ketaren, P. P. 2006 . Pengaruh Suplementasi Enzim ke dalam Pakan Mengandung Dedak Tinggi terhadap Performan Itik Pedaging. Pros. Seminar Nasional Bioteknologi. Cibinong, $15-16$ Nopember 2006. Puslit Bioteknologi, LIPI, Cibinong. hlm. $134-139$.

Matitaputty Procula R. dan Hadriana Bansi. 2016. Pertumbuhan dan Produksi Karkas Itik Lokal Gemba pada Umur 12 Minggu. Seminar Nasional Peternakan 2. Fakultas Peternakan Universitas Hassanuddin, Makassar.

National Research Council. 1994. Nutrient Requirement of Poultry. National Academy Press, Washington, D.C.

Purba, M., dan P. P. Ketaren. 2011. Konsumsi dan Konversi Pakan Itik Lokal Jantan
Umur Delapan Minggu dengan Penambahan Santoquin dan Vitamin E dalam Pakan. JITV 16 (4): 280-287.

Randa, S.Y. 2007. Bau Daging dan Performa Itik Akibat Pengaruh Perbedaan Galur dan Jenis Lemak Serta Kombinasi Komposisi Antioksidan (Vitamin A, C, dan E) dalam Pakan. Disertasi. Fakultas Peternakan, Institut Pertanian Bogor, Bogor.

Statistik Pertanian. 2017. Buku Statistik Pertanian. Kementerian Pertanian Republik Indonesia.

Suprayogi, W. P. S., Sudibyo, dan E. H. Susilo. 2017. Performa Itik Lokal Jantan (Anas plathyrynchos) yang Diberi Pakan Suplemen. Journal of Sustainable Agriculture 32 (1): 35-41.

Suryana, A. Darmawan, H. Kurniawan, Sholih, N. H, dan Suprijono. 2014. Respon Kinerja Pertumbuhan Itik Pedaging terhadap Level Protein Pakan Berbeda. Prosiding Seminar Nasional "Inovasi Teknologi Pertanian Spesifik Lokasi”. Banjarbaru. Hal 537-550. 